\title{
Rescate de la memoria histórica de la comunidad de San Pedro de Ticuantepe: oralidad e historia local
}

Recepción: 06-07-2015 / Aceptación: 10-10-2015

Ruth González García

\section{Resumen:}

El presente estudio enmarcado dentro de la historia regional y local, persigue establecer un panorama general de los orígenes de San Pedro, comunidad del municipio de Ticuantepe. De igual manera, se recogen aquellos elementos culturales propios, tales como su gastronomía, creencias, mitos, fiestas religiosas y fiestas populares. Una de las motivaciones que orientan el estudio, es el fortalecimiento de la identidad local por medio de la construcción de un pasado en común de estos habitantes.

Palabras Claves: Historia regional, historia local, fiestas populares, cultura, identidad

Abstract: This study falls from the specialty of Regional and Local History, and aims to establish an overview of the origins of San Pedro, a community in the municipality of Ticuantepe. Similarly they develop in the written cultural elements that have been identified, such as its gastronomy, beliefs, myths, religious holidays and festivals. It is necessary to state that one of the motivations that guided the study is the strengthening of local identity through the construction of this common past.

Key words: History, Popular parties, Culture, Identity

\section{Introducción}

El presente estudio es producto de una investigación en curso sobre la comunidad de San Pedro. De manera personal, el hecho de haber nacido y compartido gran parte de mi vida con esta comunidad, motivó esta tarea de registrar el pasado cuya finalidad es el fortalecimiento de lo local en el marco nacional. Esta parte que se da conocer es la primera parte de la investigación, y puede considerarse como un avance de la misma.

La investigación parte de la ausencia dentro de la comunidad de una historia escrita que vincule a las generaciones presentes y futuras con un pasado común que dé cuenta de la evolución y los cambios operados en la comunidad. En este sentido, se apeló a la memoria delos más antiguos habitantes vivos, para conocer los orígenes de la comunidad.
Para ello, se aplicaron entrevistas grabadas por medio del método de Historia Oral en ausencia de fuentes escritas- rescatando vivencias, experiencias y demás emociones que despiertan al reactivarse la memoria.

A pesar de no contarse con un documento que aborde la evolución histórica de la comunidad, se hizo trabajo documental, consultándose fuentes municipales, de los cuales se extrajeron datos que ayudaron a la comprensión de la evolución. Una fuente importante, fue la utilización de entrevistas en audio realizadas por un grupo de investigadores multidisciplinares de la UNAN Managua en el año 2008 quienes trabajaron la Historia de Ticuantepe, aplicando ---en esa ocasión--- entrevistas a miembros de la comunidad de San Pedro. Algunos de los pobladores entrevistados ya fallecieron, condición que le da a la fuente un valor significativo, por la información 
que encierra para las generaciones presentes y futuras. Las grabaciones se encuentran resguardadas como parte del acervo y patrimonio del Centro de Difusión de las Humanidades (CDIHUM).

\section{Ticuantepe municipio verde}

Ticuantepe conocido también como Municipio verde, se encuentra localizado a 14 kilómetros al sureste del departamento de Managua, en la franja del pacífico nicaragüense. Posee una significativa zona rural de fácil acceso al contarse con vías de comunicación de todo tiempo y diversa. De igual manera tiene una zona urbana pequeña, donde reside el gobierno municipal, y en las últimas décadas se ha visto un desarrollo urbanístico dinámico, en las zonas cercanas a la cabecera del Municipio. Está dividido en diez y siete comunidades, dos comarcas, un barrio y cinco repartos.

Se cree que Ticuantepe fue fundado a finales del siglo XIX por pobladores originarios de los municipios de Nindirí, Cofradía, Veracruz y poblados aledaños. En sus inicios, la comunidad estaba compuesta por doce viviendas llamadas Las Pajas, debido a los materiales que se utilizaron para edificar las primeras casas que dieron vida al lugar. Su nombre derivado del nahualt Ticune se traduce como: Tigres o fieras y Tepeh, como cerro, articuladamente "cerro de fieras".

El municipio se ha convertido en un referente ambiental en el país por la particularidad de albergar la reserva natural y de refugio de vida silvestre de gran importancia para la zona, como es El Chocoyero-El Brujo y Montibelli. Su variada flora, fauna, el gran reservorio de aguas subterráneas, suelo de origen volcánico, hace que la producción de sus principales actividades agrícolas, como la siembra de arroz, fríjoles, maíz, piña y pitaya sea de las más abundantes. La tradición en este municipio ha sido la cosecha de café y granos los básico, pero la producción de piña -en las últimas décadas-- ha hecho que el municipio sea conocido como uno de los mayores productores de este rubro.

Ticuantepe fue una comarca del municipio de Nindirí hasta el hasta el 4 de julio de 1974, fecha en que fue elevada a municipio del Departamento de Masaya, por decreto publicado en La Gaceta Diario Oficial. A partir de la regionalización emprendida por el gobierno sandinista en 1984, es incorporada política y administrativa a la Región III, que corresponde a Managua. De acuerdo a la Ley de División Política Administrativa de octubre de 1989 y sus reformas de abril de 1990, el municipio pertenece en la actualidad al Departamento de Managua.

\section{¿San Pedro o Valentín Barrios? el debate en el imaginario colectivo}

San Pedro es una de las diez y siete comunidades rurales que conforman al municipio de Ticuantepe. Su nombre oficial, registrado en la alcaldía es el de "Valentín Barrios", reconocido por el Centro de Salud y la policía local. Pese a ello, este estudio hace referencia al barrio con el nombre de San Pedro, debido a que sus habitantes se identifican como sanpedreños. El nombre de Valentín Barrios, es reciente y los habitantes no asimilan aún el cambio de nombre.

La comunidad adoptó el nombre de San Pedro al identificarse con el cementerio comunal que se encuentra en seno de esta comunidad, considerado el más antiguo del municipio, según estudios de investigación: "El primer cementerio de Ticuantepe fue el de la comunidad de San Pedro, donado por la familia Cerna" (Romero; 2008: 159). Inspirado en el "santo" que atiende la entrada de los mortales en los cielos, recuerda la gran influencia del catolicismo, abrazada por toda la comunidad. : "San Pedro se ha llamado muchos años antes de mí, por unos familiares Castros, quienes le pusieron San Pedro al panteón..." (García, 2008) En relación al nombre de Valetín Barrios, se 
inscribe dentro de los esfuerzos del gobierno revolucionario en la década de los ochenta, por rescatar la memoria de lucha de los combatientes, "bautizando" o renombrado sitios, calles o edificios con la de los mártires. En este sentido, Ángel Valentín Barrios fue un participante de la lucha insurreccional contra la dictadura somocista en la década del setenta del siglo XX.

Los nombres utilizados para los "bautizos" de sitios o lugares, en la década de los ochenta, eras seleccionados de combatientes caídos y pertenecientes a la comunidad o barrio, o de algún combatiente vinculado con la misma. Este combatiente no tiene ninguna vinculación histórica con el barrio, siendo quizás esta razón la que hace que el nombre oficial no tenga recepción entre los pobladores de la comunidad.

Según el SINAPRED, utilizando datos PELS de Ticuantepe, la comunidad Valentín Barrios (San Pedro) posee 1597 familias. Los límites son: al norte con la comunidad Madrigales Sur (Nindirí), al Sur con el barrio Medardo Andino, al este con comunidad Las Conchitas y al oeste con la comunidad Dírita y Manuel Landez.

\section{Antecedentes históricos de San Pedro}

El origen exacto de la comunidad aún se desconoce. Entre los pobladores más antiguos este dato es confuso y no se puede ubicar, aunque presumen que fue a inicios del siglo $X X$, producto de migraciones de familias pertenecientes a las comunidades aledañas.

Las casas eran construidas a base de los recursos disponibles en el medio: los techos eran de paja, las paredes de bambú o guarumo y sus divisiones internas era del mismo material. Recuerdan que, "todas las casas eran de zacate de arroz o de jaragua, en ese tiempo el zinc no se conocía, la casa de nosotros era de madera y de zacate de arroz" (Gómez, 2015)
Los informantes coinciden en que eran unas cuantas familias y recuerdan apellidos como García, Sánchez, Reynosa, Paredes:

Las primeras familias eran Hernández, Castros, Sánchez, García, Reynosa, Vallecillos. Los demás han venido después a agrandar el barrio, los primeros que han venido son de La Concepción, San Juan, San Ignacio, y hoy en día se extiende a personas de Managua, incluso de Matagalpa (García; 2008).

Los orígenes de los habitantes de San Pedro son humildes, de gente de escasos recursos, campesinos, y trabajadores. No existían escuelas, centros de salud, y el único transporte utilizados en esos primeros tiempos, eran bestias, en caso de no poseerla, estaban obligados a caminar.

\section{Espacios culturales y prácticas cotidianas}

En San Pedro han existido actividades culturales heredadas de generación en generación, permitiendo conservar viva la memoria de la comunidad a través de la oralidad. En el tema de las prácticas religiosas, y sabiendo la hegemonía del catolicismo y las dificultades de otras denominaciones cristianas por establecerse hasta mediado del siglo $X X$, se puede señalar, como lo indican los informantes, que esta fue la que inicialmente practicaban los primeros habitantes. Todas las actividades colectivas realizadas por la comunidad giraban en torno a las misas, rezos, purísimas, bautizos, procesiones, entre otras manifestaciones religiosas. Esto cambiará en las últimas décadas cuando las denominaciones cristianas hacen presencia, dejando en un segundo plano las prácticas católicas.

\section{Hábitos de alimentación}

Aunque en el municipio de Ticuantepe no se reconoce una comida de carácter típica, cuyos 
orígenes se atribuyan a los habitantes de este pequeño sector, se observan elementos que les caracterizan como nicaragüenses: el uso del maíz. Desde sus inicios, las mujeres se levantaban a tempranas horas a preparar el maíz, a molerlo y luego a hacer tortillas para todas las comidas del día. Los tamales, también figuraban entre los productos de mayor importancia, principalmente en temporada de Semana Santa. El maíz era consumido en chilote o mazorca y era común entre la población comer elotes cocidos en temporada de cosecha. En las casas de San Pedro no faltaban las güirilas, atoles, guisos y demás derivados de este cultivo.

La hospitalidad era una de las virtudes comunes que caracterizaban a las primeras generaciones de pobladores de San Pedro. Esta condición, quizá no exclusiva de este pueblo, pero de gran valor para sus miembros, se expresa en prácticas cotidianas, como la preparación de café y la degustación con los visitantes. Esta bebida era predominante y obligatoria durante el desayuno en la comunidad.

En el imaginario colectivo de la mayoría de los habitantes existía la creencia que tomar café por las mañanas era algo esencial ya que en sus actividades de trabajo los protegía de picaduras de animales peligrosos como las víboras. Ante esa eventualidad, que era muerte segura, esta bebida, podía disminuir el efecto del veneno lo que les permitiría llegar a un centro de salud y ser atendidos.

Otro de los efectos atribuidos al consumo del café, era el de analgésico, aminoraba o eliminaba el dolor de cabeza en los hombres dedicados a actividades agrícolas, expuestos a largas horas de sol. En la actualidad, las creencias sobre esta bebida y su preponderancia durante las actividades del desayuno han desaparecido entre los habitantes de San Pedro.

En cambio el arroz y los fríjoles son dos tipos de alimentos presentes de manera habitual, en la dieta de los habitantes de la comunidad, al igual que en el resto de los nicaragüenses. La mezcla de ambos, dando origen al gallo pinto, es una tradición dentro de las actividades cotidianas del desayuno o cena que recuerdan los habitantes de San Pedro como una expresión de sociabilidad familiar. La dieta diaria se completaba con el consumo de huevos, queso, crema, pollos y cerdos de patio. Estos alimentos los producían criando animales en los patios. Además sembraban para autoconsumo, yuca, hierba buena, quequisque, plátanos, cebolla, chiltoma, tomate, entre otros productos.

Los domingos la dieta habitual de la semana cambia. En la mayoría de los hogares se preparaba sopas de res la cual compartían con la familia, amigos o visitas:

Lo que la gente más comía era arroz y frijoles, queso, guiso de papa. El día domingo se bebía una buena sopa de res, en todas las casas ibas a hallar una olla de sopa. Ese día todo el mundo bebía sopa de res y si llegabas de visita te sacaban tu taza de sopa y el café negro, el cual nunca desmaya, eso ha sido usual toda la vida (Gómez, 2015)

El plátano, además de ser cosechado en los hogares de San Pedro, también provenía de las fincas localizadas en las comunidades aledañas. Una de estas era la de Arturo Bogorge, un importante productor, famoso en la zona por ser ahorrativo (lo tildaban de tacaño), quien era propietario de grandes extensiones de tierra, cuyo aspecto era poco agradable, y su dieta estaba basada en fríjoles y tortillas. Los descendientes de esta figura popular donaron la tierra donde en la actualidad funciona el campo de beisbol, bautizado con su nombre.

\section{Semana Santa}

En semana santa la dieta de los pobladores cambiaba radicalmente. Desde el inicio, se prohibía el consumo de carne de pollo, cerdo 
y res: "Desde el lunes santo ya nadie comía carne de res y de cerdo, porque decían que era pecado, no mataban res, no mataban gallina ni nada de eso hasta sábado de gloria. La gente comía sopa de queso, pinol de iguana, tamal pisque, queso, tamales" (Gómez; 2015).

Los días jueves y viernes considerados santos, eran de los más especiales durante esta semana. En estos días de gran recogimiento espiritual, de cumplían una serie de prohibiciones: no se cocinaban las comidas cotidianas, había abstinencia sexual, no se gritaba y tampoco se cultivaba la tierra. Las actividades económicas se interrumpían. Entre la dieta de estos días especiales, estaba, los tamales, rosquillas, pinol, entre otros.

La semana previa a la semana mayor se preparaban comidas y bebidas no perecederas, como tamales, queso, chicha, pinol. De manera particular, se hacían rosquillas y cosa de horno, alimentos emblemáticos en esta temporada. Era común ver los hornos en acción en las casas de las familias García, Aguirre, Sánchez, los días lunes y martes, compartido por toda la familia, amigos y allegados.

La semana santa también regulaba los comportamientos cotidianos. Un ejemplo de ello era la suspensión de los castigos a los niños, porque eran los días de sufrimiento del Señor Jesucristo y debían de guardarse. Esta práctica es sugerente por sus implicaciones, si se toma en cuenta la rigidez en la educación familiar durante esta época.

Era habitual entre los primeros pobladores, el cuido y la vigilancia en el comportamiento de menores y su actitud hacia los adultos. La rutina social -ya desaparecida-establecía el saludo con las manos juntas hacia adelante, al encontrarse con los mayores. Otra era, evitar cualquier contestación cuando se le llamaba la atención por alguna acción indebida; con pena severa se castigaba el tomar lo ajeno, o pronunciar palabras obscenas: "La educación era bien buena porque los padres sabian dominar a sus hijos, por eso no había tanto vicio como ahora, antes lo castigaban duro a uno, eran rígidos, lo sopapeaban bonito". (Gómez, 2015)

Como se señalaba arriba, durante la mayor parte de la semana santa, el niño no era castigado si cometía alguna falta. La excepción era los sábados de Gloria, cuando los malos hábitos del muchacho o niño, eran sancionados, porque se cultivaba la creencia que debía de "cantarse gloria" en el muchacho.

El sábado de Gloria también daba lugar a una actividad particular: sacar carbón. Los mayores de edad se levantaban entre las cinco y seis de la mañana a llamar a los niños que tenían menos de doce años, para ponerlos a escarbar en los patios de las casas: [A los niños] no les pegaban, hasta sábado de Gloria le estaban "quemando las costillas". Ese día los ponían a escarbar el suelo para que sacaran carbón, y los "chimbombeaban" (castigaban) a los chavalos sino sacaban. No sé cómo hallaban carbón. Ellos decían que era bueno para espantar las tormentas. Solo los niños podían escarbar. (Gómez; 2015).

Para la actividad del carbón los sábados de Gloria, los niños utilizaban objetos puntiagudos para sacar la tierra con rapidez. El que sacara la mayor cantidad de carbón según los entrevistados- era considerado un niño bueno, pues el carbón era encontrado solamente por infantes honestos cuyo comportamiento era ejemplar durante todo el año. Este ejercicio les permitía a los padres monitorear el comportamiento de sus hijos. Los menores que no encontraban carbón eran castigados para corregirlos.

Para la mayoría de los pobladores, las creencias que la semana santa promovía eran consideradas verdades inamovibles. Una de ellas, establecía que los niños no debían de correr porque si no se los tragaba la tierra. También se evitaba talar o cortar árboles porque si no, estos amanecerían con sangre, como la sangre derramada por Jesucristo. 
Los adultos alertaban e impedían que los menores se bañaran en lagos, lagunas o mares, porque se convertirían en sirenas o animales marinos.

En fin, las celebraciones iban encaminadas a fortalecer la fe católica, conmemorando la muerte de Jesucristo. Esta se expresaba en prácticas religiosas realizadas durante toda la semana, y donde los pobladores se incorporaban con entusiasmo y devoción:

La alegría en semana santa era una devoción católica, no como ahora para divertirse, era muy bonito. Anteriormente, muchos participaban en la Judea, hombres con mucha cultura jugaban bien su papel, unos de Gesta, otros de demonios, Jesús, el ángel. Era muy alegre y había más participación que hoy, porque íbamos a la procesión. Cualquier alegría ahí estábamos. La religión se debilitó (García; 2008).

Las procesiones eran organizadas en la iglesia de la cabecera municipal de Ticuantepe. Todas ellas salían de este templo principal y recorría con la imagen del santo, las calles aledañas, sirviendo de cohesionador entre la población de las comunidades rurales que participaban de manera entusiasta en el recorrido, al medio día y por las noches.

Durante las noches se realizaban las famosas Judeas, donde los pobladores organizados montaban una obra recreando muerte de Jesucristo. Los principales papeles protagonizados eran los de Judas, Gesta, ángeles, Jesús, María, entre otros. Todos los pobladores, se sentían emocionados de participar, aunque fuera de espectador. Pese a que la trama se repetía cada año, la obra nunca careció de público interesado.

\section{Imaginario popular}

\section{Creencias en los embarazos}

Entre los habitantes de San Pedro circulaban creencias relacionadas con la vida cotidiana en sus diversas expresiones. De alguna manera, obedecía a imaginarios sustentados en creencias heredades de sus antepasados. Una de ellas, muy popular, relacionada con la infidelidad, y el machismo que encierra, establecía que el hombre que negara la paternidad de un recién nacido, el niño/a saldría con las mismas características físicas de su progenitor, considerando esta situación como castigo a su desconfianza.

En el caso de las embarazadas, debían de procurase cuidados especiales para evitar deformaciones en el feto. Un ejemplo de ello, es el cumplimiento de los antojos demandados durante el proceso de gestación. Para no correr el riesgo de que sus hijos nacieran con la boca abierta, los alimentos consumidos debían ser a base de frutas, casi siempre verdes como mangos, jocotes con sal, chile y limón.

También las embarazadas debían de ser muy precavidas en tiempos de luna llena y eclipses solares. En estas circunstancias se recomendaba vestir con prendas de color negro para evitar que la luna le provocara manchas y lunares rojizos al bebé cuando naciera. Se les aconsejaba a las futuras madres no salir a la calle durante esos días para evitar que sus hijos sufrieran esos males.

\section{Plantas medicinales y parteras}

En la actualidad, la comunidad carece de un centro de salud que atienda las demandas de salud de manera inmediata entre sus habitantes. Los que requieren atención médica acuden al Hospital Amistad México-Nicaragua, localizado en el casco urbano del municipio, a diez kilómetros aproximadamente de San Pedro. 
Las carencias de atención médica cercana, ha hecho que prácticas ancestrales relacionadas con el uso de la medicina natural, se conserven. Las generaciones anteriores utilizaban plantas que se encontraban en su entorno natural para contrarrestar las enfermedades comunes que los aquejaban. De esta forma, se empezaron a transmitir los saberes medicinales de una generación a otra.

Entre las plantas que comúnmente usaban, estaban el zacate de limón para curar la tos y calentura, el cual se aplicaba mediante la elaboración de un té. El culantro, para combatir los cólicos y la hoja de mango para desinflamar cualquier parte del cuerpo. También acostumbraban aprovechar las hierbas para mejorar sus problemas de digestión, por medio de la aplicación periódica de purgantes:

Si tenían tos usaban el marango, el orégano, y el zacate de limón con dulce negro cocido. Para las diarrea buscaban el cogollo de achote, también la cascara de marañón amarillo. Para los dolores de cabeza se ponían unas plaquetas de ruda con alcohol. Las únicas pastilla que se ocupaba para el dolor era la mata dolor, y la mejoral. La sufalteasol era utilizada para las infecciones" (Gómez, 2015).

La medicina natural se convertía en la alternativa más barata, pues su uso también corresponde a la creencia de que las plantas curaban con mayor efectividad y sin efectos secundarios. Además, era un recurso accesible, siempre se podía encontrar en las huertas de sus humildes viviendas.

En ausencia de un centro de salud, las parteras eran las aliadas más eficientes de las mujeres embarazadas. Entre las más representativas están: “... Fulgencia Hernández pero le decian doña Guencha. Solamente parteaba, ella vio nacer a todos estos hombres y mujeres. A mi mamita la vio doña Tula, quien era de Ticuantepe" (Gómez, 2015;)
Las parteras también cumplían la función de sobar a las mujeres embarazadas para corregir posiciones incorrectas del bebé que impidiera la salida de este durante el parto; quitar el cordón umbilical del cuello. Cuando las mujeres se caían, también eran sobadas con el afán de emendar el daño causado durante el accidente.

Además, los sobadores también eran conocidos en estas zonas rurales. Estas personas, adiestradas por la experiencia auxiliaban a los individuos que padecían dolores a causa de músculos contraídos, huesos dislocados, extremidades hinchadas por golpes, entre otros.

\section{Celebración del Santo de la comunidad}

Todos los 29 de junio la comunidad celebra las fiestas religiosas en honor a San Pedro. A partir del triunfo de la Revolución Popular Sandinista se comenzó a celebrar con pomposidad y formas organizativas que permiten de mayor participación y proyección.

El punto de partida fue la adquisición de la imagen de San Pedro y los pobladores se organizaron para lograr este objetivo. Uno de los informantes recuerda: "Nosotros formamos una directiva -que decidió- comprar la imagen de San Pedro, después quedó en manos de la familia Aguirre, ellos son los que -actualmenteorganizan esas alegrías, incluso creo que están de acuerdo con el sacerdote" (García: 2008).

Seguidamente, se estableció una comisión encargada de la planificación de las actividades a realizar durante el transcurso de las festividades. Estas, casi siempre se hacían los fines de semana, donde se recuerdan, las corridas de pato, ventas de comidas, música y fiestas bailables por las noches. No faltaban las misas organizadas dirigidas por el cura párroco del municipio: 
En los años 80 cuando recibí el cargo de dirigente de la comunidad, formamos una directiva para hacer las alegrías de San pedro, donde hacíamos fiestas, el palo lucio, le poníamos sus cosas bonitas allá arriba, los encostalados, carreras de caballo, carreras de pato (García; 2008)

La corrida de patos era una actividad cuyos orígenes se pierden en la memoria de los habitantes, la cual era popular en las zonas rurales. Consistía la exposición sobre una cuerda, de un pato vivo con la cabeza hacia abajo, y los jinetes que competían galopaban hacía el animal con el fin de desprenderle la cabeza, el primero que lo hiciera el ganador. Era un acto cruel que los pobladores disfrutaban.

En años posteriores, atendiendo el malestar de la población ante la crueldad contra el animal, las corridas de pato fueron sustituidas por carreras de cinta, la cual se continúa practicando en la actualidad. Las cintas de colores cuelgan de una cuerda y los jinetes portando un lapicero galopan hacía los objetivos con el fin de incrustarlo en la cinta cuyo diseño redondo le permite halarlo y quedarse con ella. Este juego ha sufrido modificación en los últimos años al sustituirse el caballo por las bicicletas.

En los días previos a la corrida de cinta, se selecciona entre las muchachas más simpáticas a las candidatas a reina de la comunidad. La mayor parte de las jóvenes se involucran en la actividad organizativa, siendo para ellas un honor que el joven que se hace de mayor cantidad de cinta las escoja y les entregue el trofeo como símbolo de amistad y cariño.

Seha popularizado quenovios, pretendientes, enamorados, hermanos, primos y parientes de las candidatas participen en la corrida con el fin de proveer un mayor número de trofeos de argollas y asegurar la victoria de su favorita. La elección de la reina de San Pedro es una de las actividades de mayor arraigo y atracción entre los pobladores de la comunidad.

Otras de las actividades que se realizan durante las celebraciones del aniversario de la comunidad, es la carrera de huevos y los bailes infantiles. Esta actividad popular entre los habitantes, reúne a la familia sin distingo de edad y es una de las que más cohesiona a la comunidad. En los últimos años, la municipalidad apoya las festividades donando piñatas y dulces para que los infantes participen y se animen a quebrarlas.

La "fiesta bailable" era una actividad de gran atractivo entre los jóvenes y adultos. Se contrataba a una persona equivalente a lo que en la actualidad le llaman DJ, quien llevaba todos los equipos para amenizar la fiesta. Entre los músicos que se recuerdan con mucho cariño que amenizaban las fiestas, están Rodolfón de la Menuda, Adolfo "El Chopo".

Desde cinco años atrás, la "fiesta bailable" se ha suspendido durante las celebraciones de San Pedro debido a situaciones de violencia juvenil. Los grupos juveniles de las diversas comunidades que se daban cita, como los de Dirita, Manuel Lández, y los de San Pedro mantienen rivalidades o disputas las cuales se saldaban con enfrentamientos.

\section{Espacios de sociabilidad}

Guillermo Gómez, uno de los antiguos habitantes de San Pedro fallecido en años recientes, recordaba en la entrevista realizada en 2008 que entre la década de 1930-1950, de adolescente y ya joven, las fiestas se celebraban con músicos contratados en Masaya. Los instrumentos que usaban eran los tradicionales, bandolina, guitarra y violín. Las melodías que tocaban eran propias de la región.

Las fiestas se hacían en casas particulares, la mayoría de amplios patios. Habitualmente se 
colocaban sillas en forma de círculo, alrededor de la pista para que las damas interesadas en baile se sentaran y esperaran las solicitudes de los caballeros quienes tenían el derecho a escoger a la pareja. En ocasiones en que la dama había empeñado el baile con algún joven y de repente le apetecía bailar con otro, cumplía su promesa con el primero y le indicaba al segundo que llegara al finalizar las canciones que había comprometido con el anterior y de esa manera cumplir su compromiso sin desairar a ninguno.

En esos años de mediados del siglo XX, no había energía eléctrica y las fiestas se hacían bajo la luna llena o alumbrados con candiles colocados en puntos altos de las casas para proporcionar claridad a la pista. Muchos de los asistentes bailaban descalzos porque muchos de ellos no tenían el hábito o los recursos para adquirirlos.

Para Gladys Gómez, una generación más joven que la de don Guillermo, quien disfrutó de fiestas bailables en San Pedro, recuerda que las más populares de la comunidad eran las celebradas en casa de la familia Aguirre. Eran fiestas donde únicamente el hombre pagaba su entrada. La intrasmisible de la mujer era una sonrisa, y ya dentro del lugar, era recibida con un vaso de refresco:

Las fiestas eran en los patios con tocadiscos, con motores de luces. Los Aguirre hacían bailes pagados, el hombre pagaba y le daban su intrasmisible, un tuquito de tela con una gasillita (sujetador), eso representaba que ya había pagado, el que no anduviera eso, le andaban cobrando. La mujer no pagaba solo daba una sonrisa y su vaso de gaseosa (Gómez; 2015)

Años después, las fiestas eran celebradas con tocadiscos de baterías o eléctricos, auxilados con energía provenientes de plantas electricidad para amenizar las fiestas. Doña Gladys recuerda el ruido que hacía la planta eléctrica al fondo del patio en esos días alegres de su juventud: "Llegaban hasta las tres de la mañana con motor, la gente era rigiosa (le fascinaba) a bailar la sonora matancera, Julio Jaramillo, Cha cha cha, rock and roll y el manicero" (Gómez; 2015).

\section{Noviazgos}

Las fiestas también servían para dar paso a los noviazgos. Las jóvenes llegaban acompañadas de una chaperona que casi siempre era la madre, tía o hermana mayor. Las canciones debían de bailarse a una distancia prudente que no ocasionara comentarios malintencionados. Las parejas eran escogidas por las mujeres pero con el consentimiento de la madre, pero en caso de que ya estuvieran comprometidas se permitía más cercanía:

Cuando-los novios- iban a la fiesta eran acompañados por el mamá o el papá, se daban su besito y su abrazo cuando iban bailando, ahí estaba el viejo vigilando, una mala maniobra -les decía- venga para acá chiquita" (Gómez; 2015).

Los enamorados también aprovechaban la Semana Santa para salir a pasear, durante este tiempo gozaban de mayor libertad porque se consideraba que los habitantes eran más respetuosos, y que no se atreverían a faltarles a la novia y su familia.

De manera general los noviazgos se producían dentro de un ambiente estricto, donde la vigilancia era permanente y el respeto se imponía, los varones llegaban con su familia a casa de la novia para solicitar permiso a los padres de ella, y con esta acción demostrar sus buenas intenciones. Desde entonces en la comunidad se manejaba que la muchacha ya estaba comprometida y era vigilada:

Los noviazgos no eran ni para ver ahora, se pedian a las muchachas, dilataban jalando con sus novios y hasta que ya se conocían bien se unían en matrimonio, eran respetuosos los novios. Los padres estaban en medio de 
ellos a la hora de la visita, no se besaban ni se abrazaban" (Gómez; 2015)

Los hombres debían demostrar que merecían el cariño de su amada mediante pruebas contundentes. Entre estas estaba rajar leña y trabajo forzado que ponían al descubierto la fortaleza laboriosa del pretendiente y su capacidad de sustentar el hogar. La mujer, también atravesaba pruebas, como echar tortillas, lavar ropa, matar y destazar pollos. Ambos, hacían demostración de sus habilidades en casa de los padres de su pretendiente y futuros suegros.

La fuga de parejas amorosas era frecuente. Las fiestas populares servían como puntos de reunión para iniciar la huida. Esto, no implicaba que se celebraran ceremonias religiosas, las cuales eran sonadas en toda la comunidad. Dichas fiestas se extendían hasta al amanecer, donde se repartía comida, frescos, pastel y bebidas alcohólicas a los invitados.

\section{Quinceaños y bautizos}

Otra de las actividades que se celebraban con frecuencia en la comunidad era los bautizos y quince años. "Los quince años se hacían igual que ahora, nada cambió, con sus damas, sus caballeros" (Gómez, 2015). Ceremonias religiosas que mantienen su esencia con el paso del tiempo. El vestido rosado, las damas de honor, la comida hecha con esmero y sacrificio para degustar con los amigos y familiares durante la fiesta con la que concluye el ritual tradicional.

En cuanto a los bautizos, sigue viva la tradición de hacerlo en el seno de la religión católica. Se visten de traje blanco símbolo de la pureza del bebé, acompañado por los por los padrinos, quienes serían -en teoría-los padres sustitutos. La función del padrino se ha ido perdiendo con el tiempo, quedando únicamente como formalidad dentro del ritual religioso.
Años atrás, durante las fiestas de navidad y cumpleaños, los padrinos sentían el deber moral de llevarles regalos a sus ahijados, ropa o juguete. Una de las actividades ya perdidas, era que durante las navidades, el ahijado, entregaba una pareja de gallinas a su segundo padre. Con las manos juntas en señal de respeto saludaba a sus padrinos quienes agradecidos correspondían con un presente.

Una de las particularidades del apadrinamiento era que se realizaba entre familias, tíos muchas veces. De, de igual manera, los amigos cercanos a los padres eras invitados a fungir como padrinos. Esta unidad conocida como de compadrazgo, servía para profundizar los lazos sociales. El apadrinamiento era una responsabilidad para toda la vida.

\section{Las velas}

Otro evento que se producía con frecuencia en la comunidad eran las velas. Son espacio donde los pobladores demuestran solidaridad con la familia doliente del fallecido. Era común entre los familiares cercanos al finado, vestir de traje negro, hasta nueve días después del entierro. Durante las velas se compartía con los asistentes pan y café para mantenerlos despiertos. A media se servía un platillo de comida. Una tradición que se mantiene actualmente es que los amigos del fallecido, colaboran con pan, café y azúcar:

En las velas amanecían jugando naipe. Daban comida, café, y pan para la gente que velaba a los muertos. Esa tradición no ha cambiado. Los patios se iluminaban con candiles y candelas, el que tenía sus realitos (dinero) conseguía una planta y le ponían la luz toda la noche, pero era gente cómoda...los dueños de la música eran Arsenio y Marcial Robles, vivían en el $\mathrm{km} \mathrm{14}$, a veces traían música de 
Masaya, de la Concha, pero generalmente era la de los hermanos Robles, ya no iba la música solo el motor cuando se trataba asunto de vela, pero era gente que tenía reales (dinero) (Gómez; 2015)

Antes de la llegada de la electricidad a la comunidad, las actividades culturales o comunitarias se realizaban con candiles y candelas. En ocasiones de vela de algún fallecido, se colocaban candelas en el centro de las mesas para que los asistentes pudieran jugar cartas o ingerir licor, que era otra forma de acompañar a la familia doliente.

Era habitual que los asistentes pasaran el tiempo en grupos donde se narraban historias cuya temática, en la mayoría de los caso, giraba sobre difunto, anécdotas picantes ocurridas al narrador, conocido por todos. Entre los temas narrados también se cuenta, leyendas de aparecidos y misterios sin resolver, sobresaliendo los transmitidos por generaciones anteriores, sobre la segua, el cadejo y otros jinetes que rondaban el imaginario mítico de los pobladores.

El fallecimiento de algún miembro de la comunidad era una noticia que se sabía de manera rápida. Las redes familiares y de amistad se activaban a lo inmediato con el fin de convocar, si no todos, a la mayor parte de la comunidad, a llegar a la casa de la familia afectada. Era una tradición que todas las personas que recibían la información se sentían obligados a llegar a la casa del fallecido.

Durante la década de los 80 se implementó la introducción de "baratas", vehículos que por medio de parlantes anunciaba por las calles algún fallecimiento, indicando el nombre del fallecido, la dirección y la invitación de la familia a asistir. El aumento de la población y el proceso de cambios en las prácticas de vida material, obligó a utilizar medios automotrices y equipos de sonido, con el fin fe de informar a la comunidad del duelo.
En la actualidad en San Pedro se conservan las velas como un espacio de solidaridad con la familia afectada, pero las expresiones de vestir durante el duelo, ha cambiado. Ya no se atiende con rigurosidad el uso del color negro en los trajes, y los asistentes llegan con trajes de diversos colores, exceptuando colore estridentes como el rojo que es símbolo de festividad o celebración.

Otros cambios notados en el duelo, es la ruptura del silencio luctuoso de las casas. En el hogar del difunto y las aledañas al mismo, el respeto a la memoria del fallecido, se "pactaba" con cierta veda relacionada con diversión o fiesta. No se acostumbraba realizar actividades estridentes, encender el radio o la televisión con sonido alto. El ambiente discreto se mantenía hasta por dos meses, aunque la tradición sugiere cuarenta días.

\section{Las purísimas}

Las purísimas es otra forma de sociabilidad que ha cohesionado por generaciones a los habitantes de la comunidad. Esta festividad católica de gran ascendiente cultural es celebrada a finales de año con mucha alegría. No obstante, la llegada de otras denominaciones cristianas, a partir de la década del 90 del siglo pasado, abrazada por muchos habitantes de la comunidad, le ha quitado cierta fuerza a las purísimas.

Los altares confeccionados por los devotos de la virgen María, eran de modesta factura. El espacio donde se ubica la imagen llevaba adornos compuestos de papelillos de colores y flores frescas de madroño. En la actualidad, los altares tienen mayor elaboración, compuestas de abundantes y variadas flores y cintas de colores. Como es la tradición en el país, se reza el novenario a partir del 28 de noviembre. El día 7 de diciembre es la festividad mayor, conocida como "La gritaría", celebrada por toda la comunidad, según la tradición o costumbre de cada hogar. 
Las festividades de la noche de "La gritería" motivan a la mayor parte de los habitantes de la comunidad a salir. Algunos lo hacen por devoción otros por curiosidad o festividad. Los habitantes más antiguos recuerdan esta celebración con nostalgia:

Eran muy alegre las purísimas, ahora solo las rezan. Antes eran unos fiestones los días 7 y 8 de diciembre. Ticuantepe tronaba, tanto allí como en los lugares rurales sonaba la bailadera, había música por todos lados, los grandes bailes y las reparticiones; daban comida, chicha, nacatamales, y paquetes de gofios y caramelos, hasta unos gorritos (Gómez, 2015)

Los organizadores de los altares caseros, acopiaban golosinas y frutas que eran repartidas entre los visitantes o devotos que iban de altar en altar cantando. Los dulces o confites, de gran tradición eran degustados en canastitas de palmas y en ocasiones en cartuchos de "papel de envolver". Entre las rezadoras se recuerdan a Antonia Gómez, Brígida y Carmela Sánchez, madres e hijas respectivamente.

En la comunidad era norma no escrita que las rezadoras de las purísimas también lo hacían en las velas. Un rezo no iniciaba si alguna de estas señoras no estaba presente. Ellas gozaban de fama y respeto entre la población. A la lista de rezadoras y rezadores tradicionales se han incorporado otras vecinas, como Esperanza Sánchez, Carlos Galán, Yessenia Castro, entre otros.

En la actualidad el brindis tradicional de las purísimas ha cambiado al introducirse el envase de plástico como en panas, baldes, platos, así como recipientes de vidrio. Los caramelos siguen siendo un atractivo, pero son obsequiados en bolsas de plástico con adornos alusivos a la imagen. La comida elaborada y otras golosinas tradicionales se han mantenido en el seno de ciertas familias, como la de los Sánchez, García, Aguirre.
La tradición no perecerá en estas familias porque en la actualidad se incorporan otros miembros jóvenes para darle continuidad.

\section{Conclusiones}

Los pobladores como actores sociales son pilares fundamentales para reconstruir las vivencias de los espacios sociales que han construido en el tiempo. Es necesario que miremos hacia nuestras comunidades para garantizar el registro de sus actividades cotidianas y el rescate de lo acontecido, porque el tiempo apremia y cada día que pasa amenaza con despojarnos de los recuerdos presente en la memoria de los miembros de las comunidades o pueblos, quienes son los sujetos de los procesos históricos.

San Pedro ha percibido un cambio notable en el seno de su población. El reducido número de familias que fundaron la comunidad se ha duplicado, producto de migraciones provenientes, principalmente de Managua, Masaya, y Nindirí.

La Revolución Popular Sandinista y el establecimiento de comités permitieron el desarrollo de actividades comunales, como la celebración de las fiestas patronales en honor a San Pedro. Las celebraciones religiosas y tradicionales, constituyen uno de los principales elementos integradores y cohesionadores de la población.

A pesar de la fuerte influencia de la cultura publicitaria de consumo capitalista de los últimos tiempos, la comunidad conserva y defiende sus tradiciones y saberes los cuales forman parte de herencia identitaria de los primeros pobladores de la comunidad. Es importante destacar que la ausencia de esos fundadores no significó la erradicación de valores y tradiciones, los descendientes las continúan conservando, a la par de que se nutren de expresiones culturales externas, inevitables en la modernidad. 


\section{Referencias bibliográficas}

Barreto, P. (2002). Ticuantepe. Territorio siempre codiciado. Managua: El Guegüense.

Camarena, M, Morales T, y Necoechea, G. (1994) Reconstruyendo nuestro pasado: técnicas de Historia Oral. 1era Edición. México: Consejo Nacional para la Cultura y las Artes/Dirección General de Culturas Populares

(1964) Guerrero, J. y Soriano, L. Monografía del Departamento de Managua. Managua: s.n.

Romero, A. et.al. (2008) Ticuantepe y Su Historia. Managua: UNAN-Managua.

Rivera, J. (2010) Conociendo nuestra comunidad: una pequeña metodologia para realizar investigaciones dentro de nuestras propias comunidades. Managua: s.n.

Solano, E. (1994). Estrategias para estudiar la comunidad donde vivimos. México: EUNED.

\section{Fuentes documentales y hemerográficas}

INIFOM (2003). Ficha municipal de Ticuantepe. Managua: INFOM.
AMUNIC (1997). Ticuantepe. Managua: AMUNIC.

Revista Ticuantepe Nº1,1996.

\section{Fuentes Orales}

Manuel Sánchez, Proyecto Ticuantepe y su Historia. entrevista realizada por Marvin Villalta, San Pedro, Ticuantepe, 11 de septiembre de 2008.

Alberto Velásquez, Proyecto Ticuantepe y su Historia. entrevista realizada por Marvin Villalta, Comunidad Los Velásquez, Ticuantepe, 11 de septiembre de 2008.

Ada Luz García Jara. Proyecto Ticuantepe y su Historia. entrevista realizada por Marvin Villalta, Comunidad Manuel Landez, Ticuantepe, 10 de septiembre de 2008

Miguel García Pavón, Proyecto Ticuantepe y su Historia. entrevista realizada por Marvin Villalta, San Pedro, Ticuantepe, 10 de septiembre de 2008.

Gladys del Socorro Gómez. entrevista realizada por Ruth González García, San Pedro, Ticuantepe, 5 de abril 2015. 